\title{
Entre a Arqueologia do Saber e o Contextualismo Lingüístico: um estudo comparativo dos métodos de Michel Foucault, Quentin Skinner e John Pocock
}

\author{
Pedro Luiz Lima*
}

\section{Resumo}

O presente artigo busca contribuir teoricamente para o aprofundamento dos debates metodológicos acerca das formas de apreensão das ideias políticas. Para tal, empreende uma leitura comparativa dos principais trabalhos de Michel Foucault, Quentin Skinner e John Pocock e articula algumas relações possíveis entre a arqueologia do saber e o assim chamado contextualismo linguístico. Estabelecem-se, ao longo do texto, aproximações entre as duas vertentes, quanto ao primado do discurso e a uma pluralidade histórica de registros e contextos discursivos inconciliáveis entre si, e distinções, especialmente quanto ao lugar do sujeito na constituição das linguagens, ideias e saberes políticos.

Palavras-Chave: ideias políticas; contextualismo linguístico; arqueologia do saber; Michel Foucault; Quentin Skinner; John Pocock.

\section{Abstract}

Between archaeology of knowledge and linguistic contextualism: a comparative study on the research methods of Michel Foucault, Quentin Skinner and John Pocock

The following article is a theoretical contribution to the deepening of the methodological debates over the forms of apprehension of the political ideas. As such, it undertakes a comparative reading of the main works of Michel Foucault, Quentin Skinner and John Pocock, and articulates some possible relations between the archaeology of knowledge and the linguistic contextualism. Through the text, approximations between the two currents are established, with regards to the primacy of discourse and to the historical plurality of discursive contexts, irreconcilable with each other; and also relevant differences are pointed out, mainly with regards to the subject's place in the constitution of languages, ideas and political knowledge.

Key-words: political ideas; linguistic contextualism; archaeology of knowledge; Michel Foucault; Quentin Skinner; John Pocock.

"O logos é um grande soberano, que com o menor e mais invisível corpo, executa as ações mais divinas".

Górgias em Elogio de Helena.

\footnotetext{
* Professor Assistente de Ciência Política da Universidade Estadual de Londrina (UEL) e Doutorando do Instituto de Estudos Sociais e Políticos da Universidade do Estado do Rio de Janeiro (IESP-UERJ), Brasil. Email: pedrollima@gmail.com.
} 


\begin{abstract}
"Nós que nos julgamos ligados a uma finitude que só a nós pertence e que nos abre, mediante o conhecer, a verdade do mundo, não deveríamos lembrar-nos de que estamos presos ao dorso de um tigre?"

Michel Foucault em As Palavras e as Coisas.
\end{abstract}

A filosofia moderna, ou, para o dizermos com Habermas, o discurso filosófico da modernidade, tem talvez como seu mais determinante ponto de inflexão aquele representado pela hipóstase da linguagem enquanto elemento determinante nas experiências de sociabilidade. A partir desta linguistic turn, dentre cujos inúmeros protagonistas podemos destacar a filosofia de Wittgenstein, o universalismo de uma configuração subjetiva kantiana é, de certa maneira, suplantado por um entendimento da relação homem-mundo a partir da mediação incontornável de uma determinada linguagem.

Inscreve-se, assim, quase como premissa cognitiva, um componente de particularidade com respeito ao qual a condição humana deixa de poder ser diretamente acessada pelo reconhecimento daquelas categorias gerais conformadoras do real. Por um lado, a linguagem desloca a centralidade da antropologia kantiana, inserindo o sujeito em meio a um horizonte linguística e socialmente constituído; por outro, o real deixa de poder ser hegelianamente identificado ao racional, na medida em que a própria razão inexiste enquanto substrato imaculado da constituição humana e o real deve a sua identidade a uma apropriação linguística que the antecede e condiciona.

Neste quadro, vemos tanto o sujeito, em seus moldes kantianos, quanto a razão e o real perderem considerável quinhão de sua autonomia em prol de uma soberania da linguagem - num primado que, note-se, já fora alardeado pelo sofista Górgias bastante tempo antes de a linguistic turn passar à proa dos embates filosóficos modernos. 
Este estudo ${ }^{1}$ pretende se debruçar sobre o pano de fundo de tais embates, a partir da consideração de duas distintas abordagens filosófico-históricas que, cada uma a sua maneira, levam adiante o projeto de um pensamento pós-metafísico na segunda metade do século XX. Tratar-se-á, com efeito, de atentar para o estabelecimento de algumas possíveis relações entre as concepções arqueológicas de Michel Foucault e as noções metodológicas do que se convencionou chamar de contextualismo linguístico anglófono, a partir de seus mais eminentes representantes, Quentin Skinner e John Pocock.

Não se buscará, para fins deste estudo, realizar qualquer tipo de inventário das inúmeras possibilidades de aproximação e de afastamento que uma análise comparativa destes dois métodos poderia deixar entrever. O que se pretende, antes, é partir de alguns tópicos específicos concernentes ao primado da linguagem, ao lugar do sujeito e à noção de história resultante, para que, com relação a tais temas, se possa alcançar uma noção mais aguda da vizinhança das duas posições epistemológicas, assim como das especificidades que as caracterizariam. Para tal, algumas significativas idiossincrasias que diferenciam os dois "contextualistas" serão por vezes anotadas - mas, no nível de generalidade aqui proposto, a unidade interna do contextualismo linguístico será tomada como ponto de partida para que se torne mais nítida a contraposição metodológica. A possível precariedade de tal unidade, em outro prisma analítico, é objeto para pesquisas ulteriores.

Em geral, apesar das frequentes remissões de comentadores a plausíveis pontos de contato entre o método foucaultiano e o contextualismo linguístico (cf. Bevir, 1992, p.278 e Tully, 1988, p.16), escasseiam as investidas no sentido de um exercício mais substantivo de comparação entre os dois métodos de análise do discurso e da história. Nesse sentido, este trabalho pretende concorrer para a construção de uma compreensão mais ampla de cada uma das duas correntes a partir das consonâncias e dos ruídos que possam emergir deste encontro - constituindo-se, por conseguinte, em mais um passo na direção do delineamento dos caracteres de uma história (seja do pensamento político, seja da emergência de saberes) em que a

\footnotetext{
${ }^{1} O$ presente artigo se valeu em grande medida das sugestões e comentários dos pareceristas anônimos, a quem eu agradeço. Ademais, trata-se de trabalho feito com o suporte do CNPq (bolsa de doutorado) e da Capes (PDSE).
} 
centralidade da constituição linguística não deixa de acarretar tensões na prática do historiador.

\section{Ordem do Discurso, Primado do Contexto e Império do Paradigma}

Apesar de se voltarem para objetos diferentes, tanto o contextualismo linguístico de Skinner e Pocock quanto a arqueologia do saber de Michel Foucault alçam a linguagem a um estatuto privilegiado no que tange a suas preocupações históricas. Seja na investigação sobre as fundações do pensamento político moderno, seja na busca pelos contornos particulares às formas modernas de saber, o discurso é tomado como objeto central de análise - razão pela qual a empreitada comparativa a que se propõe este estudo se faz possível, não se dando a partir do vazio de uma heterogeneidade primeira a ser simplesmente ocupado à força por bruta aproximação.

Como, então, se pode depreender este campo comum que une Foucault e os contextualistas na referência a um primado da linguagem? De que maneira se constrói, para cada uma das duas vertentes, este plano discursivo a que suas investigações históricas remetem? Em busca de tais respostas, convém analisarmos a trajetória pela qual os autores em questão particularmente tecem suas concepções de discurso e de linguagem e a forma como estas se convertem em plano preferencial das investigações históricas.

A arqueologia do saber de Michel Foucault, como o próprio nome nos sugere, se propõe a rivalizar com uma história da ciência e uma epistemologia tradicionais. Isso porque a mera substituição do termo "ciência" pelo "saber", longe de ser acidental, funciona como indicativo de um deslocamento determinante, da análise em termos de conhecimento universalista para uma outra que toma como objeto os saberes em suas particularidades. Um primeiro movimento, pois, do método do francês talvez seja precisamente este, de cunho marcadamente nietzschiano: impor a particularidade e a precariedade de saberes, no plural, em lugar de um conhecimento 
pretensamente concebido como atributo essencial de uma constituição antropológica universalista. Instigado com a volatilidade dos saberes que testemunha na observação histórica, Foucault se questiona ceticamente a respeito de um conhecimento historicamente independente:

\footnotetext{
"Como é possível que o pensamento se desprenda desses domínios que habitava outrora e que deixe cair no erro, na quimera, no não saber aquilo mesmo que, menos de vinte anos antes, se situava e afirmava no espaço luminoso do conhecimento?" (Foucault, s/d, p.285).
}

Em As palavras e as coisas, tida por muitos como sua obra-prima, Foucault procura trazer à tona a disparidade de saberes sobre a vida, o trabalho e a linguagem no que diz respeito a duas distintas épocas históricas, a clássica e a moderna. Sua atenção particular ao período de virada da época clássica e moderna é, por um lado, sintomática da ênfase na descontinuidade representada pela revolução francesa e, por outro, já nos prenuncia uma história em que as rupturas e particularidades de cada período histórico se sobrepõem a noções históricas continuístas e totalizantes. Nesse sentido, cabe notar que, já em O Nascimento da Clínica, se trata de apontar para a diversidade nos regimes de saber no interior do qual as práticas médicas, clássica e moderna, têm sua validade avalizada. Neste ponto de suas investigações, um mesmo tipo de saber, o clínico, é exposto em sua dependência de regimes discursivos historicamente situados. Decorre, pois, da pesquisa foucaultiana, que aquele saber contemporâneo cujo caráter de cientificidade e validade universal seria mais prontamente aceito adquire aspecto contingente - em uma palavra, Foucault inscreve a prática clínica na história e, assim o fazendo, solapa seu suposto valor abrangente de verdade. O que poderia parecer universalmente válido como ciência da cura, cuja verdade e aplicabilidade transcenderiam a história, revela-se, pelo filtro foucaultiano, como precária prática de um saber cuja gênese responde menos à ingênua suposição de um primado do binômio razão-verdade na modernidade, e mais a funções e estruturas específicas de um quadro histórico (que em fase posterior, Foucault relacionará a dispositivos de saber-poder).

Já no célebre prefácio de As palavras e as coisas, a menção a Jorge Luis Borges sublinha a volatilidade característica das ordens discursivas que busca analisar. Fazendo referência a um texto do escritor argentino em que é descrita uma 
enciclopédia chinesa em sua absurda forma de catalogação de animais, Foucault exclama a inquietação que Borges causa ao expor a onipotência da linguagem e, consequentemente, a incerteza de qualquer sistema de signos. O poder da linguagem é revelado na medida em que vemos ser possível uma ordenação de seres segundo critérios os mais diversos e os mais incoerentes, quando contrastados com nossos, em si mesmos, tão certeiros critérios.

Expor, assim, a linguagem no arbitrário de seu potencial de representação inquieta, pois faz vacilar o que Foucault chama de "nossa prática milenária do Mesmo e do Outro" (Foucault, s/d, p.3). Em outros termos, a ordenação das coisas através de um arranjo de palavras, por mais estável que pareça ser, carrega sempre consigo a precariedade de se sustentar no discurso, para cuja maleabilidade Borges nos aponta. "O que faz rir quando se lê Borges aparenta-se por certo ao profundo mal-estar daqueles cuja linguagem se arruinou: ter perdido o 'comum' do lugar e do nome" (Id., Ibid., p.7).

Se nada há de mais incerto do que a instauração de uma ordem entre as coisas, é exatamente na medida em que não há ordem para além da linguagem. É curioso, assim, notar que o título da tradução em inglês de Les mots et les choses é The Order of Things - título mais irônico do que o original ${ }^{2}$, pois o objetivo parece ser precisamente o de desfazer o elo entre a ordem e as coisas. A ordem não subjaz imanente às coisas. Ela é fruto de um discurso que deve ser concebido "como uma violência que fazemos às coisas" (Idem, 2001b, p.53).

\footnotetext{
"A ordem é a um só tempo o que se oferece nas coisas como a sua lei interior, a rede secreta segundo a qual elas se olham de algum modo umas às outras, e o que não existe senão através de um olhar, de uma atenção, de uma linguagem" (Foucault, s/d, p.8).
}

\footnotetext{
2 "Certamente, coisas e palavras são termos bastante vagos para designar os dois pólos do saber, e Foucault dirá que o título As palavras e as coisas deve ser entendido ironicamente" (Deleuze, 2005, p.61).
} 
Não havendo, com efeito, uma relação de sinonímia entre palavras e coisas, a ordem das coisas submete-se à linguagem, e é neste plano da libertação das palavras de um nexo primordial com as coisas que se inscreve a heterotopia foucaultiana. Em contraposição a uma suposta função consoladora das utopias, em que um futuro de convergência essencial entre palavras e coisas é prometido, a heterotopia angustia ao se afirmar na abertura fundamental do discurso.

“(...) as heterotopias dissecam o assunto, detêm as palavras sobre si mesmas, contestam, desde a sua raiz, toda a possibilidade de gramática; desfazem os mitos e tornam estéril o lirismo das frases" (Foucault, s/d, p.6).

John Rajchman, em seu estudo sobre a obra de Michel Foucault, enfatiza o caráter heterotópico não apenas de suas considerações históricas, como também de suas representações acerca do futuro. Se a obra de Foucault nos remete incessantemente a um passado de transformações nas formações discursivas das diversas épocas tratadas, a uma pluralidade de saberes que, como já dito, carrega o elemento arbitrário da autonomia discursiva - por outro lado, aponta também para o arbitrário do futuro e, certamente, do presente. Segundo Rajchman, "as considerações de Foucault sobre o futuro são mais heterotópicas do que utópicas (...). Foucault não nos pede para esperarmos uma forma mais completa de vida, mas para imaginarmos uma época tão diferente que faça o nosso próprio tempo parecer arbitrário" (Rajchman, 1987, p.45).

Em diversos sentidos, a ordem do discurso de que nos fala Foucault se assemelha a noções fundantes da metodologia do contextualismo linguístico. Se um movimento crucial da arqueologia do saber é aquele que desloca a história da ciência e põe em dúvida seu registro universalista, os contextualistas, por sua vez, empreendem movimento em sentido semelhante quando questionam os métodos de certa história das ideias.

Para Skinner, importa combater uma noção de historiador das ideias cuja preocupação central seria a de determinar aquelas ideias universais cuja suposta onipresença nos mais variados discursos dos mais variados tempos históricos nem sequer é posta em questão. Este tipo de historiador tradicional teria, portanto, como 
tarefa primária o estudo dos textos canônicos, onde seriam encontradas as abordagens clássicas das mesmas questões perenes.

Em seu texto metodológico mais importante, Meaning and Understanding in the History of Ideas (1969), Skinner intenta construir as bases de um novo método para a história das ideias, para o que cumpre implodir os fundamentos inadequados do método a ser "ultrapassado". E tais fundamentos guardam relação, assim como na história da ciência destronada por Foucault, com uma concepção continuísta da história, envolvida sempre pelos problemas perenes de uma unívoca "grande cadeia do ser".

Não à toa, Skinner faz, por diversas vezes em seus textos de método, referência a Arthur Lovejoy como um dos pioneiros da metodologia questionada (Skinner, 2002a, p.62). Por esse viés, tem-se uma prática da história ocupada em restituir a identidade e a linearidade por sobre as diferenças e descontinuidades do devir histórico. Ora, o projeto de Skinner e Pocock, assim como o de Foucault, parece ser o de precisamente inverter esta lógica, com a centralidade da linguagem em seus estudos tendo por função ressaltar as diferenças constituintes da história. Aqui, deve-se cuidar para compreender linguagem sempre em um sentido plural: trata-se de restabelecer os vínculos de certo pensamento ou discurso político com o contexto linguístico específico que o possibilitou. A linguagem entra, pois, na análise destes historiados do discurso político como operador de contingências, no sentido de romper com a imagem plácida de uma história conduzida univocamente na direção de uma suposta resolução de seus perennial issues.

Neste ponto, as similitudes entre o projeto foucaultiano e o do contextualismo linguístico são especialmente profícuas. De um lado, vemos Foucault, ao definir o seu método, asseverar que "a arqueologia toma por objeto de sua descrição o que habitualmente se considera obstáculo: ela não tem por projeto superar as diferenças, mas analisá-las, dizer em que exatamente consistem e diferenciá-las" (Foucault, 1995, p.195). De outro, pode-se flagrar Pocock utilizando o mesmo imagético do francês para 
construir uma concepção do historiador não muito distante do elogio foucaultiano das diferenças:

\footnotetext{
“O historiador é, em larga medida, um arqueólogo. Ele está comprometido com a descoberta da presença dos vários contextos linguísticos nos quais o discurso foi realizado em determinados momentos" (Pocock, 2003, p.67).
}

A ideia, como símbolo ideal de constantes históricas, perde, pois, definitivamente seu lugar de objeto preferencial, em uma história preocupada com as diferenças e suas manifestações nos diversos contextos e linguagens. Nesse sentido, pode-se identificar nos contextualistas um ceticismo fundamental com relação à possibilidade mesma de realização de uma história em termos de ideias ou conceitos gerais uniformes. Como veremos, o apego ao "ato-de-fala" e ao discurso positivado aproxima os autores de um pragmatismo cético - e mantém oculta a dificuldade (apenas sugerida neste artigo) de esta "escola" dar conta do componente inconsciente dos discursos. O não-dito persistiria, talvez, como obstáculo.

No artigo supra-citado, Skinner elabora o seu ceticismo: "I remain skeptical about the value of writing histories of concepts or 'unit ideas'. The only histories of ideas to be written are histories of their uses in argument" (Skinner, 2002a, p.86). E Pocock, por sua vez, parece em seguida continuar o mesmo argumento skinneriano, quando afirma a intangibilidade da ideia concebida abstratamente e toma o discurso e a linguagem como única chave de acesso para uma história do pensamento político:

\footnotetext{
"Ao insistir em que o pensamento deve ser enunciado para poder ter uma história, e que tal história pode ser vista como uma interação entre o ato de fala e a linguagem, demos o primeiro e crucial passo, embora não o último na direção da construção de nossa história como uma história do discurso" (Pocock, 2003, p.64).
}

Esta história do discurso deve, em parte, sua efetividade à superação das mitologias que Skinner vê embasarem a prática do historiador das ideias tradicional. Mitologias estas que concorreriam para aguçar a insensibilidade de tal historiador às particularidades - ou, como atesta Foucault, que fazem com que a diferença passe a obstáculo e não objeto da análise.

A mitologia das doutrinas remete à já comentada assunção de um conjunto de ideias perenes que necessariamente devem fazer parte do repertório dos autores 
analisados. Esta ilusão da perenidade de temas faz com que se impute aos autores estudados teorias alheias ao próprio escopo do seu pensamento, pois, mais uma vez, trata-se de impor um universalismo abstrato a pensamentos particulares cujo entendimento requer a especificação de cada contexto discursivo. Preso à abstração universalista, o historiador das ideias incorreria no mais temível de todos os erros, qual seja, o do anacronismo - pois esta mitologia da doutrina leva-o a condenar a ausência de reflexões sobre qualquer um dos temas mitologicamente alçados ao posto de assuntos necessários de toda reflexão política. Quando não condena os autores passados, o historiador das ideias imputa à sua obra uma contribuição para debate futuro cujos termos necessariamente se revelam estrangeiros ao contexto original do autor em questão. Com a reificação da doutrina e sua transformação em entidade trans-histórica (Skinner, 2002a, p.62), exige-se do discurso analisado que se vincule ou expresse contribuições ao desenvolvimento de um tema cuja construção perpétua só pode ser considerada na ignorância dos contextos linguísticos do discurso. Para o historiador contextualista, com efeito, trata-se não de construir um debate entre o autor estudado e a doutrina imaginada, mas antes de "recuperar as questões específicas às quais os textos filosóficos estudados foram projetados como resposta" (Idem, 2001, p.177).

Pela mitologia da coerência, interpretar a obra de um autor implica buscar uma unidade que, superando possíveis contradições e mudanças de perspectivas, culmine numa representação coesa e indiferenciada de sua teoria. Aqui, aquela visão metafísica de uma história contínua desce ao nível da obra. Se a contradição, no domínio histórico, deve repercutir numa síntese final conciliadora, também para os textos clássicos analisados ela não passa de obstáculo artificial a ser superado como falsa aparência. É curioso notar que esta tendência metafísica apontada por Skinner na história das ideias (Idem, 2002a, p.70) é também sublinhada, no outro lado da Mancha, por Michel Foucault em termos bastante similares. Segundo o francês, " $a$ história das ideias, normalmente, dá um crédito de coerência ao discurso que analisa. 
(...) Ela se encarrega de encontrar, em um nível mais ou menos profundo, um princípio de coesão que organiza o discurso e Ihe restitui uma unidade oculta" (Foucault, 1995, p.171).

Com a terceira mitologia, a da prolepse, o anacronismo é mais uma vez o alvo primeiro, pois se trata de atentar para o costume mitológico de se interpretar textos a partir de significados futuros, completamente alheios ao contexto original de enunciação discursiva. Nesse sentido, pode-se interpretar Platão e Rousseau como fundadores do totalitarismo, quando tanto o termo quanto a prática histórica totalitária estavam muito além do horizonte discursivo em que aqueles autores se situavam. Por esta via mitológica, abre-se a possibilidade de julgamento moral de autores do passado - num passo universalista que Skinner veementemente refuta, fazendo referência a Leo Strauss e a por ele suposta imoralidade dos escritos de Maquiavel. Estes exercícios anacrônicos tornar-se-iam meios de imposição de preconceitos presentes a autores e contextos passados: "History then indeed becomes a pack of tricks we play on the dead" (Skinner, 2002a, p.65).

Por fim, a quarta e última mitologia descrita por Skinner é a da influência. Como as outras, a mitologia da influência parece concorrer para a construção de uma narrativa histórica totalizante, na medida em que suprimiria rupturas e descontinuidades enlaçando a heterogeneidade discursiva sob a insígnia pouco precisa da influência. Se a história das ideias tem como pilares alguns mesmos perennial issues, e se estes são tratados coerentemente pelos autores ao longo de suas obras, também é de se esperar que entre estes autores não haja lacunas ou fronteiras assaz rígidas. Assim é que o recurso à noção de influência funciona como elo entre contextos históricos nunca admitidos em sua particularidade. Não por coincidência, Foucault também deplora, assim como Skinner, a função metafísica da influência enquanto conceito próprio a uma história da identidade ${ }^{3}$.

As mitologias funcionam, pois, como precauções de método para o historiador do pensamento político, que deve se mover não mais na direção de uma

\footnotetext{
3 "O mesmo ocorre com a noção de influência, que fornece um suporte - demasiado mágico para poder ser bem analisado - aos fatos de transmissão e de comunicação; que atribui a um processo de andamento causal (mas sem delimitação rigorosa nem definição teórica) os fenômenos de semelhança ou de repetição; que liga, à distância e através do tempo - como por intermédio de um meio de propagação -, unidades definidas como indivíduos, obras, noções ou teorias" (Foucault, 1995, p.24).
} 
fenomenologia da ideia perene, mas sim em busca da reconstrução histórica de contextos de enunciação. Trata-se, enfim, de construir uma história da dessemelhança e da variedade, como Skinner deixa claro no trecho seguinte:

\footnotetext{
"as soon as we see that there is no determinate idea to which various writers contributed, but only a variety of statements made by a variety of different agents with a variety of different intentions, what we are seeing is that there is no history of the idea to be written" (Skinner, 2002a, p.85).
}

Se em Foucault o deslocamento da análise em temos da ciência para outra concernente aos saberes substitui uma noção de verdade por uma outra, de validade situada, aqui também, para dar conta desta variedade de contextos, é preciso que o historiador deixe de lado a dicotomia verdadeiro/falso na análise de discursos. Em resposta a indagações de Charles Taylor a respeito do lugar da questão da verdade em suas pesquisas (Taylor, 1988, p.220), Skinner defende que a importância da verdade para o tipo de investigações históricas que considera seria exagerada (Skinner, 1988b, p.256). O seu ponto é, antes, o de que, abandonando uma concepção substantiva de razão, torna-se possível alcançar os requisitos capazes de the proporcionar um acesso à racionalidade contextualizada do discurso estudado. Em suas próprias palavras, "what we need to employ is solely the concept of rational acceptability, not that of truth" (Id., ibid. , p.257).

Esta aceitabilidade racional seria vária, e a sua apreensibilidade decorreria da precisa descrição do contexto que circunda o discurso analisado. O objeto de Skinner e Pocock situa-se, pois, a meio caminho entre uma extrema localização, em que só se leva em consideração o próprio texto do autor em questão, e uma oposta extrema universalização, em que parte-se da ideia perene para descendentemente conferir sentido a enunciações particulares. Neste meio do caminho se encontra precisamente o contexto - objeto privilegiado da análise, na medida mesma em que dá conta de uma inscrição social e histórica do discurso, para além de uma noção atomística de significado (Skinner, 1988b, p.252) e aquém de sua compreensão universalista. O 
sentido que se quer recobrar reside substancialmente no meio linguístico em que se situa a enunciação analisada. Para o historiador contextualista,

\footnotetext{
"The primary task is therefore that of trying to recover a particular context of presuppositions and other beliefs, a context that serves to exhibit the utterance in which we are interested as one that it was rational for that particular agent, in those particular circumstances, to have held to be true" (Skinner, 1988b, p.247).
}

A esta altura, este primado do contexto apregoado por Skinner, com a sua consequente noção de racionalidade situada, nos remete à adoção por Pocock da concepção de paradigma herdada da epistemologia kuhniana. Interessa, para nossos fins nesse estudo, apontar para a compatibilidade existente entre esta concepção contextualista de paradigma e a noção foucaultiana de episteme.

Tanto Foucault quanto Pocock conferem precedência a um estudo da linguagem que alcance um nível de regularidade dos discursos e enfatize a heterogeneidade de regimes paradigmáticos/epistêmicos. Assim como a história foucaultiana busca reconhecer as mudanças epistêmicas que, como já citamos acima, conferem volatilidade a regimes discursivos, fazendo com que se mova a fronteira do válido e do verdadeiro de uma episteme para outra; também Pocock se ocupa desta mesma volatilidade, prescrevendo uma história definida como "a history of change in the employment of paradigms, the exploration of paradigms and the employment of paradigms for the exploration of paradigms" (Pocock, 1989, p.23).

Muitas vezes se utilizando de termos como "textura paradigmática" e ressaltando os muitos níveis simultâneos de paradigmas, Pocock atenta para a pluralidade de contextos linguísticos encontrados pelo historiador-arqueólogo tal como ele o define (Pocock, 2003, p.70). Não há, portanto, a postulação de um paradigma que unilateralmente definiria o conteúdo do discurso que se formula em seu interior. A existência de uma pluralidade de sublinguagens, com seus padrões de polivalência (Id., 2003, p.32), assegura que o discurso não deve ser entendido como mero espelho perfeito da sublinguagem a que se filia, mas antes como mosaico de um intrincado jogo de sublinguagens que a erudição do historiador é capaz de destrinchar.

Tal como o paradigma de Pocock, mas se voltando para o seu objeto particular que consiste na relação ciência-saber, a episteme de Foucault atende também pela 
conferência de uma regularidade em meio à qual se instaurariam as práticas discursivas possíveis e se definiria o marco divisório entre o verdadeiro e o falso. Frisando a pluralidade de práticas e de regimes discursivos constituintes da episteme de uma dada época, Foucault atesta que sua episteme

\footnotetext{
"não é uma forma de conhecimento, ou um tipo de racionalidade que, atravessando as ciências mais diversas, manifestaria a unidade soberana de um sujeito, de um espírito ou de uma época: é o conjunto das relações que podem ser descobertas, para uma época dada, entre as ciências, quando estas são analisadas no nível das regularidades discursivas" (Foucault, 1995, p.217).
}

Neste ponto, vemos Foucault refutar de antemão a interpretação equivocada de seu projeto histórico que o assimilaria àquele de Hegel. Tanto Richard Rorty (1984, p.72) quanto Henning (1987, p.183) aproximam noções foucaultianas como as de episteme e arquivo com concepções hegelianas de espírito de época, com relação às quais o filósofo-historiador francês faz questão de se afastar. A episteme, cabe notar, não é a forma mais acabada do volksgeist ou do zeitgeist de um determinado período histórico. Trata-se, antes, de uma constituição movida por uma contínua dinâmica em que a episteme não é repercussão necessária do devir histórico, sendo, muito pelo contrário, configurada por acontecimentos singulares e contingentes.

Em Foucault, assim como para o contextualismo, não há correspondência imediata entre real e racional. Em grande medida, a primazia da linguagem, aliada à sua precariedade intrínseca, evidencia um divórcio entre realidade e razão que não dá margem a futuros reencontros. No lugar da razão entram as palavras, cuja relação com a realidade das coisas nós já vimos ser não de reflexo plácido, mas de violência.

Esta função de autoridade implícita em determinados usos da linguagem, em que se trata de adjudicar quanto ao grau de verdade e ao estatuto científico de proposições, também é percebida por Pocock. Tanto que o autor neozelandês chega a identificar o paradigma como uma constelação conceitual com funções de autoridade no discurso político de uma dada sociedade (Pocock, 1989, p.277). Em suas próprias 
palavras, "to view language as we have viewed it here is to view it as consisting of paradigms which simultaneously perform an indefinite number of linguistic and social functions, which enjoin and entail an indefinite number of authority structures" (Id., Ibid., p.286). Aqui, talvez não seja de todo estéril o exercício de contrapor citações, já que Foucault parece tratar de sua noção de episteme em termos bastante próximos aos de Pocock, quando escreve que "a episteme, ainda, como conjunto de relações entre ciências, figuras epistemológicas, positividades e práticas discursivas, permite compreender o jogo das coações e das limitações que, em um momento determinado, se impõem ao discurso" (Foucault, 1995, p.217).

Se a ordem, em Foucault, no que tange às concepções de vida, trabalho, linguagem ou até mesmo prática clínica, decorre de um determinado regime discursivo e da peculiar vontade de verdade que o atravessa (Idem, 2001b, p.20); também para Pocock, de modo não muito díspar, os paradigmas preponderantes em determinados contextos determinam os regimes de interdição e validação discursiva no que tange ao debate político. Poderíamos, assim, falar em um império, ao mesmo tempo imponente e precário, do paradigma, em meio ao qual os discursos devem se alojar em busca de qualquer efetividade, mas cujo poder, linguisticamente constituído e portanto independente de qualquer verdade transcendental, está continuamente posto à prova nos jogos de embates discursivos.

Pudemos, até aqui, observar alguns pontos de aproximação entre a arqueologia do saber e o contextualismo linguístico. Por um lado, vimos como ambos colocam em suspenso a questão da verdade, voltando sua história para saberes e discursos cuja validade situada independe de qualquer subordinação a critérios imutáveis. Esta apreensão da lógica contextualizada de discursos e da eficácia local dos saberes constitui, notadamente, o objetivo de uma história avessa a teleologias e linearidades, construída na ênfase ao descontínuo e à diferença. Por outro lado, na medida em que a diferença e a mutabilidade de práticas discursivas e contextos linguísticos substituem uma história tradicionalmente realizada sob a premissa da identidade e continuidade, o historiador está desprovido de sintomas utópicos e pode apenas abraçar a causa da heterotopia. Assim, se para Foucault "o papel da filosofia não é forçosamente o de adocicar a existência dos homens e prometer-lhes algo como uma felicidade" 
(Foucault, 1994, p.543), tampouco para Skinner deve-se buscar na história do pensamento a solução para problemas imediatos (Skinner, 2002a, p.89). Em suma, ambos os métodos históricos concorrem para o solapamento de uma concepção presentista, apontando para o presente não como o termo necessário de um desenrolar histórico progressivo, mas como o estado contingente de uma trajetória acidentada e em disputa ${ }^{4}$.

\section{Entre a intenção e o pensamento do exterior: a questão do sujeito}

Enquanto na seção anterior atentávamos para alguns pontos possíveis de convergência entre a arqueologia do saber e o contextualismo linguístico, convém, a esta altura - uma vez estabelecido este solo comum -, retomar alguns caracteres de ambos os métodos que os caracterizam não mais em sua aproximação, mas sim em seu distanciamento recíproco.

Talvez como emblema principal desta divergência, podemos perceber um tratamento diferenciado no que concerne ao papel do sujeito ou do autor nas distintas concepções de discurso e linguagem das duas vertentes. Sigamos, pois, em princípio, Foucault e o lugar por ele dispensado à figura do sujeito, para que na sequência vejamos a disparidade da sua análise tomada em relação a dos contextualistas.

Ao deslocar, como vimos, a questão do conhecimento de um plano da verdade e da ciência verdadeira a outro, de saberes e de possibilidades discursivas, Foucault abandona também a noção de sujeito do conhecimento com características cognitivas universais. Vai ainda mais longe, e situa o sujeito como o elo dependente em sua

\footnotetext{
${ }^{4}$ Segundo Habermas, um dos principais objetivos da arqueologia de Foucault seria o de "abandonar $a$ consciência de tempo presentista da modernidade (...), romper com o privilégio concedido a um presente marcado pela pressão problemática da assunção responsável do futuro e referido com narcisismo ao passado" (2002, p.350). Quanto à relação com o presente de seu método histórico, tantas vezes acusado de antiquarismo, Skinner afirma: "The investigation of alien systems of belief provides us with an irreplaceable means of standing back from our prevailling assumptions and structures of thought, and of situating ourselves in relation to other and very different forms of life" (Skinner, 1988, p.286).
} 
relação com o discurso e com a linguagem. Não apenas não é o sujeito universal quem constrói seus campos de significados, como tampouco se pode ver no sujeito, tomado em suas particularidades, o agente primordial do discurso. A linguagem, diz-nos Foucault, "não é falada por ninguém: todo o sujeito nela desenha apenas uma dobra gramatical" (Foucault, 2001a, p.50). O sujeito seria, assim, um mero reprodutor de algo cuja produção o antecede - e parece ser nesses termos que Foucault narra os contornos de "uma linguagem sem sujeito determinável, uma lei sem deus, um pronome pessoal sem personagem" (Id., ibid., p.44).

A dependência do sujeito no domínio do saber é afirmada de maneira mais direta em $A$ arqueologia do saber. Nesse texto, em que o método arqueológico é exposto pela primeira vez de forma sistemática, vê-se Foucault buscar construir um modelo de análise da história do pensamento em oposição à história das ciências e à epistemologia. Nestes dois métodos, Foucault encontra a mesma remissão a um sujeito de conhecimento que enlaça e uniformiza as mais variadas formas de produção de conhecimento ao longo da história. Ora, o objetivo de Foucault passa a ser então expressamente o de "libertar a história do pensamento de sua sujeição transcendental" (Idem, 1995, p.230). Por isso também, efetua-se a já referida dissociação entre saber e ciência, tão cara ao método foucaultiano, na medida em que "a arqueologia encontra o ponto de equilíbrio de sua análise no saber - isto é, em um domínio em que o sujeito é necessariamente situado e dependente, sem que jamais possa ser considerado titular" (Id., Ibid., p.207).

Parece obscura, à primeira vista, esta noção de uma linguagem e de um discurso que se situam para além de um sujeito enunciador. Como conceber este "pensamento do exterior" de que nos fala Foucault? A esse respeito, Gilles Deleuze parece fornecer uma pista interessante, quando na passagem seguinte faz referência à questão da exterioridade do pensamento:

"O apelo ao lado de fora é um tema constante em Foucault, e significa que pensar não é o exercício inato de uma faculdade, mas deve suceder ao pensamento. Pensar não depende de uma bela interioridade a reunir o visível e o enunciável, mas se dá sob a intrusão de um lado de fora que aprofunda o intervalo, e força, desmembra o interior" (Deleuze, 2005, p.94). 
O esforço principal de Foucault parece ser no sentido de renunciar ao apelo a uma unidade subjetiva entendida como fonte primordial dos enunciados. Este próprio conceito, o de enunciado, que inevitavelmente remete a um enunciar que exige sujeito, é determinado pelas formações discursivas que lhe são anteriores. 0 enunciado, antes de ser vinculado a um sujeito formulador, deve remeter à formação discursiva em que se situa, à episteme em que se aloja, ao campo delimitado dos saberes que viabilizam o discurso verdadeiro e demarcam a fronteira do falso - "o enunciado não remete a nenhum cogito" (Deleuze, 2005, p.16).

Por esta via interpretativa, o que parece ser sugerida é a importância da virtualidade dos sujeitos, antes mesmo de sua realidade efetiva. Ou seja, o agente discursivo real é secundário frente a um alojamento das possibilidades subjetivas que Ihe antecede. E é nesse sentido que Deleuze toma o enunciado como "função primitiva anônima, que só permite subsistir o sujeito na terceira pessoa e como função derivada" (Id., Ibid., p.26).

Em um texto-conferência de 1969 (O que é um autor?), Foucault trata diretamente deste tema, adotando como objeto uma posição específica e privilegiada de sujeito discursivo, o autor. A partir desse escrito, pode-se depreender os caracteres gerais de sua recusa do sujeito. Primeiramente, o objetivo parece ser o de rejeitar uma concepção individualizante de desenrolar histórico. Não se busca, como a retórica de Merquior faz crer, retirar de "quaisquer seres humanos" a responsabilidade pelas transformações históricas ${ }^{5}$. Antes, o que se quer é evidenciar a impossibilidade de se pensar tais transformações, ou mesmo quaisquer eventos discursivos, sem ultrapassar uma lógica individualizante que não dá conta da complexidade dos fenômenos sociais. Foucault se põe, assim, a tratar da questão do autor, exatamente porque esta "constitui o momento forte da individualização na história das ideias, dos conhecimentos, das literaturas" (Foucault, 1992, p.33).

\footnotetext{
${ }^{5}$ Para José Guilherme Merquior, em seu apanhado crítico sobre a obra de Foucault, "o amplo uso que ele faz de verbos pronominais, do vago pronome on e de outros artificios verbais" faz com que se evite "especificamente imputar processos sociais a quaisquer seres humanos" (Merquior, 1985, pp.163-164).
} 
O propósito passa a ser, então, como já notamos, inverter a lógica de funcionamento do discurso, e dar ao sujeito um estatuto de terceira pessoa, como indica Deleuze. De agente do discurso, temos um sujeito que passa a objeto de uma precedente ordem do discurso:

\begin{abstract}
"Não mais pôr a questão: como é que a liberdade de um sujeito se pode inserir na espessura das coisas e dar-lhe sentido, como é que ela pode animar, a partir do interior, as regras de uma linguagem e tornar desse modo claros os desígnios que lhe são próprios? Colocar antes as questões seguintes: como, segundo que condições e sob que formas, algo como um sujeito pode aparecer na ordem dos discursos? Que lugar pode o sujeito ocupar em cada tipo de discurso, que funções pode exercer e obedecendo a que regras? Em suma, trata-se de retirar ao sujeito o papel de fundamento originário e de o analisar como uma função variável e complexa do discurso." (Foucault, 1992, p.69-70).
\end{abstract}

Se, portanto, para Foucault o sujeito deixa de ser fundamento e passa a, ele mesmo, ser fundado pela lógica externa de um discurso que regula as possibilidades de atuação subjetiva, resta verificar em que medida os contextualistas se afastam desta perspectiva e constroem um lugar diferenciado para o sujeito na rede de linguagens por eles tecidas. Para tal, devemos seguir Skinner em sua aplicação da teoria dos atos de fala e Pocock em sua descrição da dinâmica de interações entre langue e parole.

Fundamentando o seu método a partir da teoria da linguagem de John Austin, Skinner adota o conceito de utterance e distingue entre o seu sentido, sua força ilocucionária e suas intenções perlocucionárias. No primeiro destes três níveis, o sentido se relaciona àquilo que o texto em sua superficialidade apresenta ao leitor/receptor. Aqui, é a consistência gramatical e a coerência semântica que permitem a compreensão do sentido, estando este afixado e restrito ao significado das palavras enunciadas.

Por sua vez, a intenção perlocucionária diz respeito àquilo que o escritor pretende causar no receptor com a emissão de determinada utterance. Concerne, pois, aos efeitos posteriores à enunciação motivados intencionalmente pelo emissor. Neste caso, é importante fazermos apelo à língua inglesa, já que é em sentença de árdua tradução que Skinner define o perlocucionário como "what they may have intended by writing in a certain way" (Skinner, 2002b, p.99). O grifo no termo by indica 
que se trata de tomar o escrito como meio para se considerar suas consequências ulteriores provavelmente pretendidas. Além disso, o foco parece sair da pura textualidade e se voltar para a relação do texto com a sua apreensão. 0 registro perlocucionário se situaria, assim, entre o texto, ou ato de fala, e a sua recepção, reconstituindo um elo entre a intenção por detrás da emissão e suas repercussões exteriores.

Já a força ilocucionária remete a um diferente aspecto do ato comunicativo aspecto este que, com efeito, mais interessa Skinner na sua apropriação da teoria de Austin. Trata-se, enfim, não mais de se inquirir sobre o conteúdo do speech act (aquilo que é dito), nem tampouco a respeito do que se pretendeu por meio de determinado ato de fala, mas sim quanto àquilo que o emissor fazia ao proferir sua mensagem. Voltando-se para as enunciações tomadas enquanto atos e, por conseguinte, focando sobre os agentes, Skinner define a intenção ilocucionária como "what they may have intended in writing in a certain way" (Id., Ibid.). Há que se atentar, nesta dimensão linguística, para a exclusão de considerações sobre a realização efetiva posterior de intenções precedentes - o ponto aqui não reside nas consequências, mas nas intenções cristalizadas no ato mesmo de comunicação.

A história do pensamento político projetada por Skinner ultrapassa, portanto, a mera análise textual, assim como não se resume a um estudo das recepções. Para aferir as intenções ilocucionárias subjacentes aos importantes movimentos desta história, compete ao historiador situar o sentido não do texto em si, mas antes do ato imanente de que este texto é manifestação derradeira. Em suma, trata-se de pensar as obras analisadas como atos de comunicação, pressupondo-se que "any act of communication constitutes the taking up of some determinant position in relation to some pre-existing conversation or argument" (Idem, 1988b, p.274). Nesse sentido, o texto deve a sua compreensão histórica densa a uma inscrição no seu contexto originário. Como vimos na seção anterior deste estudo, o objetivo de Skinner é não mais o de referir os autores e suas obras a uma constelação de ideias gerais ou 
conformá-las sob a égide do verdadeiro ou ideológico; a sua intenção é, antes, a de restituir o contexto discursivo em que o sentido substantivo das diversas proposições políticas pode ser apreendido.

Para Skinner, então, deve-se pensar os escritos sob análise como movimentos em si mesmos políticos. Isso porque a necessidade do intérprete de inscrever o texto no contexto revela a dimensão política destas próprias expressões, no modo como se relacionam com o seu meio, visando alterá-lo ou conservá-lo. Quanto a isso, Kari Palonen aponta para uma extensão do conceito de evento político em Skinner, fazendo com que este abarque a própria atividade do pensar (Palonen, 2003, p.17). Seria a descoberta desta dimensão política do pensamento o principal feito do que Palonen não se furta a denominar de revolução skinneriana (Id., Ibid., p.175).

Desta politização do discurso decorre o imperativo de interpretá-lo a partir das intenções ilocucionárias que a sua inscrição no contexto encerra. $E$, assim sendo, podese enfim notar que o autor, ou o sujeito que enuncia, não detém aquele aspecto apagado e fugidio que possui na caracterização foucaultiana. Ao contrário, Skinner remete a compreensão do discurso à reconstituição intencional que, necessariamente, faz apelo a um sujeito ativo.

É preciso, contudo, observarmos mais detidamente a conceituação de intenção no vocabulário de Skinner, para que não nos precipitemos na crítica falaciosa que supõe no método contextualista o intento de acessar a consciência dos autores estudados (Femia, 1988, pp.159-161). Neste caso, a consternação do crítico é respondida diretamente em seu "A reply to my critics":

\footnotetext{
"Of course we cannot hope to step into the shoes of past agents, still less into their minds. But it does not follow that we cannot hope to recover the intentions with which their utterances were issued, and hence what they meant by them. The reason is that the intentions with which anyone performs any sucessful act of communication must, ex hypothesi, be publicly legible" (Skinner, 1988b, p.279).
}

Esta cláusula de publicidade das intenções, que a noção de força ilocucionária já denotava, afasta definitivamente a pretensão de recuperação de consciências íntimas. Nessa mesma direção, é interessante notar que Skinner constantemente fala de intenções corporificadas (embodied) em atos de comunicação lingüística (Idem, 
2001, p.185). Enquanto os motivos do autor dizem respeito a uma condição anterior a seu ato comunicativo e, portanto, permanecem inacessíveis à investigação histórica, as intenções não são similarmente intangíveis, uma vez que as obras podem ser entendidas como corporificação de intenções e objetivos particulares ("embodiment of a particular aim or intention") - cuja intervenção comunicativa no contexto requer sua expressão em termos publicamente inteligíveis (Idem, 2002b, p.98).

A importância da intencionalidade para a história de Skinner não remete, como corolário necessário, a um primado do sujeito no ato comunicativo. Ao contrário, como já vimos, a primazia permanece no regime discursivo e no contexto linguístico tal qual o historiador insistentemente enfatiza: "It is certainly an implication of my approach that the idea of discourse, not individual authors, becomes the main focus of attention" (Idem, 1988b, p.276). Assim, se por um lado Skinner demonstra uma preocupação similar a de Foucault quanto a refutação de uma concepção atomística de construção discursiva (Id., Ibid., p.252), por outro o historiador britânico mantém-se ainda fiel à figura do autor: "I certainly wish to cleave to the figure of the author, and I certainly think it indispensable to the interpretation of texts to find out what the author may have meant" (Id., Ibid., p.269).

Admitindo, pois, uma importância relativa do papel do autor na trama discursiva, Skinner pretende, não se detendo no quadro sincrônico de certa sublinguagem ou episteme, dar conta do momento de inovação, a partir do qual as convenções linguísticas sofrem um abalo e são obrigadas a se recompor de uma nova maneira. Assim é que, pelo seu método, longe de aprisionar as possibilidades criativas do autor atrás da jaula de ferro de regimes discursivos cerrados, o historiador busca exatamente o oposto, isto é, partir de um conhecimento do contexto para ser apto a reconhecer a inovação e seu impacto transformador (Skinner, 1988a, p.106).

Por sua vez, Michel Foucault, com sua noção de episteme, parece mesmo intentar a elisão do sujeito em seu papel criativo. Sua ênfase na regularidade discursiva sugere, por vezes, um método incapaz de relacionar diacronicamente as estruturas 
sincrônicas (Henning, 1987, p.158). Em oposição aparente, pois, à consideração skinneriana da criatividade e da inovação, a arqueologia do saber pretendia revelar que "todo enunciado se relacionava a uma certa regularidade - que nada, por conseguinte, podia ser considerado como pura e simples criação, ou maravilhosa desordem do gênio" (Foucault, 1995, p.168).

Entretanto, há que se cuidar para não reduzirmos a rica contribuição foucaultiana a um insípido holismo linguístico com relação ao qual o próprio Foucault fez questão de se distanciar. Se dentre os seus projetos se pode encontrar a realização de uma histoire événementielle, então a importância do evento, do acontecimento, indica que não há aqui uma ossificação do discurso. O filósofo é, quanto a isso, claro:

\footnotetext{
"É preciso renunciar a todos esses temas que têm por função garantir a infinita continuidade do discurso e sua secreta presença no jogo de uma ausência sempre reconduzida. É preciso estar pronto para acolher cada momento do discurso em sua irrupção de acontecimentos" (Foucault, 1995, p.28).
}

Não se substitui, portanto, o autor ou o sujeito por uma estrutura impávida que se manifestaria em todas as proposições e enunciados. A recusa do sujeito, em Foucault, em vez de ser interpretada como mero abandono de qualquer possibilidade de ação subjetiva em prol da estrutura - como sugere Axel Honneth ${ }^{6}$-, talvez deva ser concebida como a superação de certa noção de sujeito, em que são postos em cheque o seu transcendentalismo e a universalidade dos seus atributos.

Uma vez que "um enunciado é sempre um acontecimento que nem a língua nem o sentido podem esgotar inteiramente" (Foucault, 1995, p.32), então, antes de associarmos diretamente a elisão do sujeito à perenização da episteme, é preciso conceber uma forma de movimento histórico que não passa pela ação unívoca de um sujeito consciente. Nas últimas páginas de seu tratado metodológico, Foucault se defende manifestamente de tais acusações de enrijescimento histórico: "I have not denied - far from it - the possibility of changing discourse: I have deprived the

\footnotetext{
${ }^{6}$ Para o crítico,"em vez de questionar a singularidade do sujeito histórico, a quem as realizações constitutivas são atribuídas, e substituí-la por um mais convincente modelo de uma pluralidade de atores históricos, Foucault adota a perspectiva oposta de uma eliminação do conceito de sujeito em geral" (Honneth, 1991, p.119-120).
} 
Sovereignty of the subject of the exclusive and instantaneous right to it" (Idem, Apud: Poster, 1987, p.151)

Enquanto em Skinner a consideração do elemento diacrônico reside no estabelecimento de uma margem de criatividade e de um poder transformador do sujeito/autor, em Foucault a mudança não depende da intenção autoral. A exterioridade do pensamento, que tanto insiste em sublinhar, passa por transformações não vinculadas à interioridade volitiva de sujeitos, mas à estrutura interna dos discursos (Poster, 1987, p.151), em que o sujeito e o autor, cabe lembrar, representam funções específicas.

Os escritos metodológicos de Pocock, por sua vez, oferecem talvez um quadro mais facilmente apreensível da dinâmica das linguagens explorada pelo método contextualista. Utilizando-se da terminologia da linguística saussuriana, a versão de Pocock da interação entre autor e contexto torna a história do pensamento político "uma história da fala e do discurso, das interações entre langue e parole" (Pocock, 2003, p.28). Por este vocabulário, a langue representa o que antes chamávamos de paradigmas ou sublinguagens, ou seja, estruturas discursivas mais ou menos fixas, em meio às quais a parole aparece como enunciados singulares, portadores de um potencial renovador da própria estrutura linguística em que se aloja. Apesar da particularidade de seus termos, é possível depreender desta noção de interação entre langue e parole a afinidade entre a sua perspectiva e a de Skinner. Ambos, em contraste com a investida foucaultiana para uma ruptura com a noção de sujeito e de seus vestígios metafísicos, reabilitam a figura do autor, concedendo a este uma decisiva margem no processo de renovação e transformação dos contextos linguísticos. Nesse sentido, Pocock defende que "um autor é tanto o expropriador, tomando a linguagem de outros e usando-a para seus próprios fins, quanto o inovador

\footnotetext{
${ }^{7}$ A utilização da tradução em inglês do texto de Foucault, neste específico caso, se deu devido à precariedade da tradução brasileira em que se lê: "Longe de mim negar a possibilidade de mudar o discurso: tirei dele o direito exclusivo e instantâneo à soberania do sujeito" (Foucault, 1995, p.237).
} 
que atua sobre a linguagem de maneira a induzir momentâneas ou duradouras mudanças na forma como ela é usada" (Pocock, 2003, p.29).

Há, assim, uma dupla face nas linguagens tal como os contextualistas a entendem: elas constituem tanto uma limitação quanto um recurso para a prática discursiva (Skinner, 1988b, p.276). Se há, em certo sentido, a prevalência do sincrônico nas análises tanto dos contextualistas quanto do arqueólogo do saber, esta se dá na medida em que "linguagens e discursos são estruturas complexas cujos componentes existem simultaneamente no tempo" e, portanto, "estudá-los é apostar no sincrônico" (Pocock, 2006, p.85). Por outro lado, na linguagem reside a própria chave de resolução desta suposta antinomia entre diacronia e sincronia, uma vez que "as linguagens têm como atributo a continuidade, tanto quanto a transformação" (Idem, 2003, p.30).

O sujeito, portanto, através da figura do autor, incide na perspectiva contextualista como instância dinamizadora, através da qual se movimentam diacronicamente as diversas texturas linguísticas componentes de um dado contexto. Neste ponto, pois, vemos afastarem-se as duas vertentes aqui contrapostas, já que Foucault tem como tarefa fundamental de sua arqueologia o dissipar a noção de sujeito de uma suposta função originária de todo o discurso. Para o francês, a prática discursiva deve ser analisada como conjunto de regras anônimas (Foucault, 1995, p.136), em que se busca precisamente apartar o enunciado de sua suposta relação imperativa com uma subjetividade soberana (Id., Ibid., p.141).

Depreende-se da discussão sobre o lugar do sujeito nas diferentes concepções históricas uma relevante divergência. Pois se o empreendimento histórico de Foucault requer a superação do sujeito como passo crucial para afastar as ilusões continuístas e teleológicas de uma história das ideias ou da ciência; em Pocock e Skinner, por outro lado, a mesma recusa a tal noção tradicional de história se manifesta com o auxílio da categoria do autor como variável inabdicável para a compreensão das linguagens e dos discursos políticos em sua dinâmica.

\section{Considerações Finais}

Buscamos, neste estudo, desenvolver alguns pontos de contato e outros movimentos de afastamento entre o método arqueológico de Michel Foucault e o 
contextualismo linguístico de Quentin Skinner e John Pocock. Explorando os múltiplos sentidos do termo logos, pode-se dizer que, para ambas as perspectivas históricas, trata-se de superar um logocentrismo metafísico para o qual a história seria o palco de desvelamento progressivo da razão, substituindo-o por um logocentrismo historicizado em que a linguagem e os discursos são, em sua precariedade e regularidade, as chaves de acesso a mundos passados e heterogêneos.

O logos secularizado, entendido no sentido de um Górgias ou até mesmo de um Jorge Luis Borges, passa ao centro, como vimos, destas concepções históricas em que o descontínuo e a contingência vêm deslocar noções de identidade e necessidade, caracteres gastos de uma filosofia da história e de uma história das ideias contra as quais se voltam os autores aqui estudados. No que se aproximam, tanto Foucault quanto Skinner e Pocock conferem primado ao discurso, ao contexto e ao paradigma ou sublinguagem; primado, este, no sentido de opor a universalismos e idealismos o localismo e o arbitrário (relativo) de regimes discursivos e padrões de sociabilidade particulares. Assim, sua história não quer reduzir as diferenças observadas a qualquer forma de narrativa abrangente; trata-se, em suma, de uma história que se volta para a diferença e a analisa em sua positividade heterotópica.

Por outro lado, vimos também como estes projetos históricos semelhantes encerram dissonâncias significativas entre si. Neste sentido, pôde-se notar a significativa discrepância entre a elisão do sujeito perpetrada pela arqueologia de Foucault e a consideração contextualista do autor enquanto peça chave nos movimentos de estabilização e transformação dos contextos e das sublinguagens.

Permanece, contudo, aberta a tarefa de intensificar este trabalho de comparação entre os dois métodos, não apenas para melhor caracterizar o jogo de proximidades e distanciamentos, como também para esmiuçar a aparente tensão, inscrita nas duas abordagens, entre perspectivismo e positivismo. Pois uma vez realçada a diferença e a particularidade de contextos e linguagens passadas em relação às presentes, restaria por determinar como se deixam apreender estas lógicas 
discursivas díspares sem a interferência indevida dos paradigmas de onde fala o historiador. O risco do ciclo hermenêutico é, pois, profícuo ponto de partida para futuras investidas comparativas.

\section{Referências Bibliográficas}

Bevir, Mark. 1992. "The Errors of Linguistic Contextualism". History and Theory, vol. 31, n. 3, pp. 276-298.

Deleuze, Gilles. 2005. Foucault. São Paulo: Editora brasiliense.

Femia, Joseph V. 1988. "An historicist critique of 'revisionist' methods for studying the history of ideas", in Tully, James (ed.), Meaning and Context. Quentin Skinner and his critics. Princeton, Princeton University Press, pp. 156-175.

Foucault, Michel. s/d. As Palavras e as coisas. Lisboa, Portugália Editora.

Foucault, Michel. 1992. O que é um autor? Vega/Passagens.

Foucault, Michel. 1994. "L’homme est-il mort?", in Dits et Écrits (vol.I). Paris, Gallimard, pp. 540-544.

Foucault, Michel. 1995. A arqueologia do Saber. Rio de Janeiro, Forense Universitária.

Foucault, Michel. 2001a. O Pensamento do Exterior. Fim de Século.

Foucault, Michel. 2001b. A ordem do discurso. São Paulo, Loyola.

Henning, E. M.. 1987. "Archaeology, Deconstruction, and Intellectual History", in LaCapra, Dominick e Kaplan, Steven L., Modern European Intellectual History. Reappraisals and New Perspectives. Ithaca/London, Cornell University Press, pp. 153-196.

Honneth, Axel. 1991. The Critique of Power. Cambridge: MIT Press.

Palonen, Kari. 2003. Quentin Skinner. History, Politics, Rhetoric. Cambridge, Polity.

Pocock, John G. A. 1989. Politics, Language and Time. Chicago/London, The University of Chicago Press.

Pocock, John G. A. 2003. Linguagens do Ideário Político. São Paulo, Edusp.

Pocock, John G. A. 2006. "Conceitos e discursos: uma diferença cultural? Comentário sobre o paper de Melvin Richter", in Jasmin, Marcelo Gantus e Feres Júnior, João (orgs.), História dos Conceitos; debates e perspectivas. Rio de Janeiro, Puc-Rio/Loyola/IUPERJ, pp. 83-96.

Poster, Mark. 1987. "The Future According to Foucault: The Archaeology of Knowledge and Intellectual History", in LaCapra, Dominick e Kaplan, Steven L., Modern European Intellectual History. Reappraisals and New Perspectives. Ithaca/London, Cornell University Press, pp. 137152.

Rajchman, John. 1987. A liberdade da filosofia. Rio de Janeiro: Jorge Zahar. 
Rorty, Richard. 1984. "The historiography of philosophy: Four Genres", in R. Rorty, J.B. Schneewind e Q.Skinner (eds.), Philosophy in history. Cambridge, Cambridge University Press, pp. 49-75.

Skinner, Quentin. 1988a. "Some Problems in the analysis of political thought and action", in Tully, James (ed.), Meaning and Context. Quentin Skinner and his critics. Princeton, Princeton University Press, pp. 97-118.

Skinner, Quentin. 1988b. "A Reply to my critics", in Tully, James (ed.), Meaning and Context. Quentin Skinner and his critics. Princeton, Princeton University Press, pp. 231-288.

Skinner, Quentin. 2001. "The Rise of, challenge to, and Prospects for a Collingwoodian Approach to the history of Political Thought", in D. Castiglione e I. Hampsher-Monk (orgs.), The History of Political Thought in National Context. Cambridge, Cambridge University Press, pp. 175-188.

Skinner, Quentin. 2002a. "Meaning and Understanding in the history of ideas", in Visions of Politics (vol I: Regarding Method). Cambridge, Cambridge University Press, pp. 57-89.

Skinner, Quentin. 2002b. "Motives, intentions and interpretation", in Visions of Politics (vol I: Regarding Method). Cambridge, Cambridge University Press, pp. 90-102.

Taylor, Charles. 1988. "The Hermeneutics of Conflict", in Tully, James (ed.), Meaning and Context. Quentin Skinner and his critics. Princeton, Princeton University Press, pp. 218-228.

Tully, James. 1988. "The pen is a mighty sword: Quentin Skinner's analysis of politics", in Meaning and Context. Quentin Skinner and his critics. Princeton, Princeton University Press, pp. 7-25. 